\title{
Pengaruh Model Pembelajaran Kooperatif Tipe Picture and Picture terhadap Kompetensi Belajar Peserta Didik pada Materi Sistem Ekskresi Kelas XI MAN 3 Pesisir Selatan
}

\author{
Vahmil Riffani Hadi ${ }^{1}$, Relsas Yogica ${ }^{2}$, Ardi $^{3}$ \\ 12)3) Jurusan Biologi, FMIPA, Universitas Negeri Padang, Padang, Indonesia \\ Pengiriman: 13 Nopember 2019; Diterima: 25 Nopember 2019; Publikasi: Nopember 2019
}

\begin{abstract}
Curriculum hasn't been done as expected in MAN 3 Pesisir Selatan. Another problem are the mindset of the students about biology that a lot of theory and pictures are dificult to understand, low learning motivation, and the learning model applied by the dominant teacher lecture method. This study aims to determine the effect of the cooperative learning model picture and picture type on student's learning competencies on Excretion System material of class XI MAN 3 Pesisir Selatan. This type of research is a quasi experimental design randomized control group posttest only design. The research population was all student in class XI MAN 3 Pesisir Selatan enrolled in the 2018/2019 year which amounts to two class. Sampling technique using saturation sampling, class XI MIA 1 as the experimental class and class XI MIA 2 as the control class. Knowledge instrument in the form of posttest, attitude and skill instrument in the form of observation sheet. The data analysis technique used is the $t$ test which is first carried out a prerequisite test, namely the normality test and homogenity test. Based on the result of research on the competency of student knowledge gained value tcount $>$ ttable $(2,68>1,67)$, attitude competence tcount $>$ ttable $(3,27>1,67)$ and skill competence tcount $>$ ttable $(1,89>1,67)$. This proves that the hypothesis is accepted. The conclusion was that the application of cooperative learning model picture and picture type had a positive effect on student's learning competencies on Excretion System material class XI MAN 3 Pesisir Selatan.
\end{abstract}

Keywords: Picture and Picture, Cooperative Learning, Learning Competencies, Excretion System

ABSTRAK: Penerapan kurikulum 2013 di MAN 3 Pesisir Selatan belum berjalan sesuai harapan. Masalah yang ditemukan yaitu siswa yang menganggap biologi merupakan pelajaran yang banyak teori dan gambar sehingga sulit dipahami, motivasi belajar rendah, dan model pembelajaran yang diterapkan oleh guru adalah dominan metode ceramah. Penelitian bertujuan untuk mengetahui pengaruh model pembelajaran kooperatif tipe picture and picture terhadap kompetensi belajar siswa pada materi Sistem Ekskresi kelas XI MAN 3 Pesisir Selatan. Jenis penelitian ini adalah quasi experimental design randomized control group posttest only design. Subyek penelitian adalah siswa kelas XI MAN 3 Pesisir Selatan tahun 2018/2019 yang berjumlah dua kelas. Teknik pengambilan sampel menggunakan sampling jenuh, kelas XI MIA 1 sebagai kelas eksperimen dan kelas XI MIA 2 sebagai kelas kontrol. Instrumen pengetahuan berupa instrumen posttest, sikap dan keterampilan dalam bentuk lembar observasi. Teknik analisis data yang digunakan adalah uji t dengan uji prasyarat, yaitu uji normalitas dan uji homogenitas. Berdasarkan hasil penelitian kompetensi pengetahuan siswa diperoleh nilai thitung $>$ ttabel $(2,68>1,67)$, kompetensi sikap thitung $>$ ttabel $(3,27>1,67)$ dan kompetensi keterampilan thitung > ttabel $(1,89>1,67)$. Ini membuktikan bahwa hipotesis diterima. Dapat disimpulkan bahwa penerapan model pembelajaran kooperatif tipe picture and picture berpengaruh positif terhadap kompetensi belajar siswa pada materi Sistem Ekskresi kelas XI MAN 3 Pesisir Selatan.

Kata Kunci: Picture and Picture, Pembelajaran Kooperatif, Kompetensi Pembelajaran, Sistem Ekskresi

*Penulis Korespondensi:

Alamat surel: vahmilriffani17@gmail.com 


\section{PENDAHULUAN}

Pembelajaran merupakan suatu proses komunikasi yang melibatkan tiga komponen pokok; yaitu komponen pengirim pesan (guru), komponen penerima pesan (peserta didik) dan komponen pesan. Saat ini Indonesia menerapkan pembelajaran dengan Kurikulum 2013 yang menuntut peserta didik untuk lebih berperan aktif dalam proses belajar. Kurikulum 2013 menilai 3 aspek yaitu pengetahuan, sikap dan keterampilan. Dalam hal ini, keberhasilan dalam mencapai pembelajaran berkualitas juga ditentukan oleh model pembelajaran yang digunakan oleh guru sehingga peserta didik termotivasi untuk belajar. Hal ini didukung oleh pendapat Trianto (2009: 8) bahwa dalam proses pembelajaran seorang guru harus bijaksana menentukan suatu model yang sesuai sehingga dapat menciptakan situasi dan kondisi kelas yang kondusif agar proses belajar mengajar dapat berlangsung sesuai dengan tujuan yang diharapkan.

Hasil wawancara yang peneliti lakukan pada tanggal 10 Januari 2019 di Madrasah Aliyah Negeri (MAN) 3 Pesisir Selatan dengan ibu Mudawati S.Pd menjelaskan bahwa sekolah tersebut sudah menerapkan kurikulum 2013 namun belum sepenuhnya terlaksana dengan baik. Pembelajaran yang diterapkan terlihat monoton karena cenderung berpusat kepada guru. Hal ini tidak sesuai dengan arahan Kurikulum 2013 yang dalam pelaksanaannya melibatkan keaktifan peserta didik lebih banyak.

Berdasarkan observasi yang peneliti lakukan, perhatian peserta didik terlihat cukup rendah dalam pelajaran biologi seperti kurang aktif dalam diskusi dan proses tanya jawab hanya didominasi oleh peserta didik tertentu saja. Menurut peserta didik, materi biologi cenderung hafalan dan banyak gambar yang sulit dipahami. Pola pikir peserta didik tersebut menjadi salah satu penyebab rendahnya motivasi untuk belajar. Motivasi belajar yang rendah dapat mengakibatkan lemahnya pemahaman konsep materi pembelajaran.

Kecenderungan guru mengajar dengan metode ceramah, diskusi dan tanya jawab yang monoton menyebabkan sebagian peserta didik pasif dalam pembelajaran. Hal ini berdampak pada kompetensi pengetahuan dan sikap peserta didik. Berdasarkan observasi peneliti pada kompetensi keterampilan, terlihat bahwa peserta didik lebih antusias untuk melaksanakan pembelajaran jika diminta untuk unjuk kerja secara langsung.

Melihat kondisi tersebut, perlu adanya upaya guru untuk meningkatkan kualitas pembelajaran dengan cara menerapkan model pembelajaran inovatif yang sesuai. Salah satu model pembelajaran yang dapat mengatasi masalah tersebut adalah menggunakan model pembelajaran kooperatif tipe picture and picture. Model picture and picture mengarahkan peserta didik untuk langsung unjuk kerja dalam proses pembelajaran yang dapat melibatkan semua potensi dirinya sehingga hasil belajar menjadi lebih baik. Untuk mengantisipasi pembelajaran sebelumnya yang monoton, model picture and picture ini menerapkan pembelajaran yang menyenangan, sehingga peserta didik lebih terpacu untuk berkompetisi dalam belajar, dalam hal ini kompetensi belajar dapat meningkat.

Alvin (2016: 3) dalam penelitiannya menyatakan bahwa dengan menggunakan model pembelajaran picture and picture didapatkan hasil belajar siswa pada ranah kognitif di kelas eksperimen persentase ketuntasannya lebih baik dari pada kelas kontrol. Seiring dengan pernyataan tersebut, Riyono (2015: 171) menyatakan bahwa penerapan model pembelajaran picture and picture memudahkan siswa dalam memahami materi. 
Pembelajaran dengan model picture and picture membuat siswa aktif bekerja kelompok, berdiskusi, demonstrasi dan tanya jawab. Taniredja (2013: 55) menyatakan bahwa pembelajaran kooperatif picture and picture merupakan sistem pembelajaran yang memberi kesempatan pada peserta didik untuk bekerja sama dalam menyelesaikan tugas-tugas berstruktur, berkelompok, sehingga terjadinya interaksi secara terbuka dan hubungan yang baik diantara anggota kelompok.

Fitriani dan Mahwar (2018: 19) dalam penelitiannya menyatakan bahwa proses pembelajaran picture and picture ini dapat membantu peserta didik untuk belajar dengan baik dan peserta didik akan lebih aktif dalam mengikuti pembelajaran. Haryaman (2017: 10) juga menunjukkan bahwa penggunaan model picture and picture terbukti efektif meningkatkan proses pembelajaran dan keaktifan peserta didik. Sama halnya dengan penelitian yang dilakukan oleh Natalina (2011: 19) bahwa penerapan picture and picture ini dapat meningkatkan hasil belajar biologi peserta didik.

Berdasarkan masalah yang dikemukakan, maka peneliti melakukan penelitian yang berjudul pengaruh model pembelajaran kooperatif tipe picture and picture terhadap kompetensi belajar peserta didik pada materi sistem ekskresi kelas XI MAN 3 Pesisir Selatan.

\section{METODE PENELITIAN}

Penelitian ini dilaksanakan pada semester genap Tahun Ajaran 2018/2019. Penelitian ini merupakan penelitian kuasi eksperimen dengan desain penelitian randomized control group posttest only design. Peneliti menggunakan sekelompok subyek penelitian dari suatu populasi, kemudian dikelompokkan secara random menjadi dua kelas, yaitu kelas eskperimen dan kelas kontrol. Pada kelas eksperimen diberikan perlakuan dengan model pembelajaran kooperatif tipe picture and picture, sedangkan kelas kontrol tidak diberikan perlakuan dengan model pembelajaran picture and picture. Selanjutnya diberi posttest pada kedua kelas sampel.

Populasi dalam penelitian ini adalah seluruh kelas XI di MAN 3 Pesisir Selatan yang terdaftar pada tahun ajaran 2018/2019 yang meliputi dua kelas. Sampel penelitian ditentukan dengan menggunakan teknik saturation sampling. Penelitian ini dilaksanakan selama enam pertemuan (12 JP). Instrumen penelitian yang digunakan untuk menilai kompetensi pengetahuan berupa tes akhir (posttest), kompetensi sikap menggunakan lembar observasi sikap dan rubrik penilaian, dan kompetensi keterampilan menggunakan lembar observasi proyek dan rubrik penilaian. Lembar observasi sikap dan keterampilan beserta rubrik penilaiannya dikembangkan dari paduan penilaian Direktorat Pembinaan SMA Ditjen Pendidikan Dasar dan Menengah tahun 2017. Instrumen penilaian kompetensi pengetahuan, sikap, dan keterampilan divalidasi oleh dosen jurusan biologi UNP dan guru biologi MAN 3 Pesisir Selatan.

Tahapan (sintaks) pembelajaran dalam penelitian untuk kelas eksperimen sebagai berikut: 1) Penyampaian Kompetensi; 2) Presentasi Materi; 3) Penyajian Gambar; 4) Pemasangan Gambar; 5) Penjajakan; 6) Penyajian Kompetensi; 7) Kesimpulan. Data penelitian ini dianalisis menggunakan uji statistik. Data kompetensi pengetahuan menggunakan uji $\mathrm{t}$ yang terlebih dahulu dilakukan uji normalitas dan uji homogenitas. 


\section{HASIL DAN PEMBAHASAN}

\section{A. Hasil Penelitian}

Berdasarkan penelitian yang dilakukan di MAN 3 Pesisir Selatan pada bulan April sampai Mei 2019 dengan sampel penelitian peserta didik kelas XI MIA 1 dan XI MIA 2 diperoleh hasil penelitian untuk kompetensi pengetahuan pengetahuan, sikap, dan keterampilan.

1. Kompetensi pengetahuan

Hasil penelitian tentang pengaruh model pembelajaran picture and picture terhadap kompetensi pengetahuan peserta didik, dapat dilihat pada Tabel 1 .

Tabel 1. Data Kompetensi Pengetahuan Peserta Didik Kelas Sampel

\begin{tabular}{|c|c|c|c|c|}
\hline \multirow[t]{2}{*}{$\overline{\text { No. }}$} & \multirow[t]{2}{*}{ Parameter } & \multicolumn{2}{|c|}{ Kelas } & \multirow[t]{2}{*}{ Ket } \\
\hline & & $\overline{\text { Eksperimen }}$ & Kontrol & \\
\hline 1 & Rata-Rata & 76,15 & 67,14 & $\overline{\mathrm{x}} 1>\overline{\mathrm{x}} 2$ \\
\hline \multirow[t]{2}{*}{2} & Uji & $-0=0,13$ & $\mathrm{~L} 0=0,15$ & Terdistri \\
\hline & Normalitas & \multicolumn{2}{|c|}{$\mathrm{Lt}=0,173 \mathrm{Lt}=0,161$} & $\begin{array}{l}\text { busi } \\
\text { Normal }\end{array}$ \\
\hline \multirow[t]{2}{*}{3} & Uji & \multicolumn{2}{|c|}{ Fhitung $=0,68<$} & Fhitung< \\
\hline & $\begin{array}{l}\text { Homogeni } \\
\text { tas }\end{array}$ & \multicolumn{2}{|c|}{ Ftabel $=1,92$} & $\begin{array}{l}\text { Ftabel } \\
\text { Varians } \\
\text { Homogen }\end{array}$ \\
\hline \multirow[t]{2}{*}{4} & $\begin{array}{l}\text { Uji } \\
\text { Hipotesis }\end{array}$ & \multirow{2}{*}{\multicolumn{2}{|c|}{$\begin{array}{l}\text { thitung }=2,68>\text { tabel } \\
=1,67\end{array}$}} & thitung> \\
\hline & & & & $\begin{array}{l}\text { Hipotesis } \\
\text { Diterima }\end{array}$ \\
\hline
\end{tabular}

2. Kompetensi sikap

Hasil penelitian tentang pengaruh model picture and picture terhadap kompetensi sikap peserta didik, dapat dilihat pada Tabel 2.

Tabel 2. Data Kompetensi Sikap Peserta Didik Kelas Sampel

\begin{tabular}{|c|c|c|c|}
\hline \multirow[t]{2}{*}{ No. Parameter } & \multicolumn{2}{|c|}{ Kelas } & \multirow[t]{2}{*}{ Ket } \\
\hline & Eksperimen & Kontrol & \\
\hline Rata-Rata & 76,46 & 66,54 & 2 \\
\hline
\end{tabular}

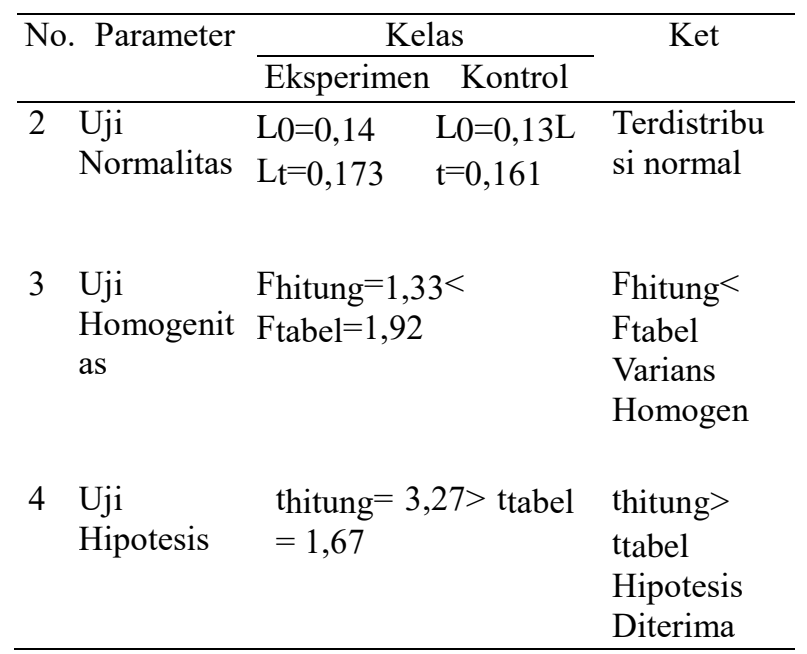

3. Kompetensi keterampilan

Hasil penelitian tentang pengaruh model problem based learning (PBL) bermuatan literasi sains terhadap kompetensi keterampilan peserta didik, dapat dilihat pada Tabel 3 .

Tabel 3. Data Kompetensi Keterampilan Peserta Didik Kelas Sampel

\begin{tabular}{|c|c|c|c|c|}
\hline \multirow[t]{2}{*}{ No. } & \multirow[t]{2}{*}{ Parameter } & \multicolumn{2}{|c|}{ Kelas } & \multirow[t]{2}{*}{ Ket } \\
\hline & & Eksperimen & Kontrol & \\
\hline 1 & Rata-Rata & 86,81 & 81,39 & $\bar{x} 1>\bar{x} 2$ \\
\hline 2 & $\begin{array}{l}\text { Uji } \\
\text { Normalitas }\end{array}$ & $\begin{array}{l}\mathrm{L} 0=0,13 \\
\mathrm{Lt}=0,173\end{array}$ & $\begin{array}{l}\mathrm{L}_{0}=0,14 \\
\mathrm{Lt}_{\mathrm{t}}=0,161\end{array}$ & $\begin{array}{l}\text { Terdistribu } \\
\text { si normal }\end{array}$ \\
\hline 3 & $\begin{array}{l}\text { Uji } \\
\text { Homogenit } \\
\text { as }\end{array}$ & $\begin{array}{l}\text { Fhitung }=1, \\
\text { Ftabel }=1,9\end{array}$ & & $\begin{array}{l}\text { Fhitung< } \\
\text { Ftabel } \\
\text { Varians } \\
\text { Homogen }\end{array}$ \\
\hline 4 & $\begin{array}{l}\text { Uji } \\
\text { Hipotesis }\end{array}$ & $\begin{array}{l}\text { thitung }=8, \\
=1,67\end{array}$ & $0>$ ttabel & $\begin{array}{l}\text { thitung> } \\
\text { ttabel } \\
\text { Hipotesis } \\
\text { Diterima }\end{array}$ \\
\hline
\end{tabular}

Berdasarkan Tabel 1,2 dan 3 uji normalitas data pada kedua kelas sampel memiliki L0<Lt hal ini berarti data terdistribusi normal. Hasil uji homogenitas didapat Fhitung $<$ Ftabel hal ini berarti data yang diperoleh memiliki varians yang homogen. Hasil uji normalitas dan uji homogenitas terbukti data yang terdistribusi normal dengan varian homogen maka dilanjutkan dengan uji t, hasil yang didapatkan thitung $>$ ttabel sehingga 
hipotesis diterima.

\section{B. Pembahasan}

1. Kompetensi Pengetahuan

Berdasarkan hasil pengujian hipotesis menyatakan ada perbedaan kompetensi pengetahuan antara kelompok siswa yang menggunakan model picture and picture bermuatan literasi sains dengan kelompok siswa yang tidak menggunakan model pembelajaran picture and picture, hal ini diperkuat dengan nilai rata-rata kelas eksperimen 76,15 sedangkan ratarata nilai kelas kontrol 67,14 , dari analisis tersebut terlihat rata-rata kompetensi pengetahuan model picture and picture lebih tinggi dari kompetensi pengetahuan pada kelas yang tidak menggunakan model pembelajaran picture and picture.

Uji normalitas menunjukkan bahwa data kedua kelas sampel terdistribusi normal. Hal ini dibuktikan dengan hasil uji normalitas pada kelas eksperimen dengan L0 0,13 dan Ltabel pada taraf nyata 0,05 yaitu 0,173 . L0 < Ltabel maka data terdistribusi normal. Kelas kontrol memiliki L0 0,15 dan Ltabel pada taraf nyata 0,05 yaitu 0,161 menunjukkan bahwa data terdistribusi normal karena L0 < Ltabel. Selanjutnya peneliti melakukan uji homogenitas pada kelas sampel. Hasil uji homogenitas diperoleh Fhitung 0,68 dan Ftabel 1,92 dengan taraf nyata 0,05. Hal ini menunjukkan Fhitung < Ftabel, maka data memiliki varians yang homogen. Berdasarkan uji normalitas dan uji homogenitas yang menunjukkan bahwa data terdistribusi normal dan memiliki varians yang homogen maka peneliti melakukan uji hipotesis untuk mengetahui apakah terdapat pengaruh positif pada penggunaan model pembelajaran picture and picture. Berdasarkan uji hipotesis yaitu uji t diperoleh thitung 2,68 dan ttabel 1,67 dengan taraf nyata 0,05 . thitung > ttabel, maka H1 diterima dan H0 ditolak. Artinya terdapat pengaruh positif yang berarti pada penggunaan model pembelajaran picture and picture terhadap kompetensi pengetahuan peserta didik pada materi sistem ekskresi di MAN 3 Pesisir Selatan.

Kompetensi pengetahuan peserta didik dalam pembelajaran mengunakan model picture and picture lebih tinggi dibandingkan peserta didik dengan pembelajaran tidak mengunakan model pembelajaran picture and picture karena pada model picture and picture peserta didik diarahkan untuk dapat berperan aktif dalam proses pembelajaran melalui media gambar yang diberikan guru sehingga memberikan dampak positif terhadap hasil kompetensi pengetahuan peserta didik. Guru menampilkan gambar yang harus disusun, diberi keterangan dan penjelasan oleh peserta didik dapat meningkatkan perhatian dan semangat dalam mengikuti pembelajaran dan memancing kompetisi antar masing-masing kelompok belajar sehingga dapat meningkatkan kompetensi pengetahuan peserta didik. Hal ini diperkuat oleh penelitian yang dilakukan oleh Yundani (2017:7) yang menyatakan bahwa pembelajaran dengan menggunakan model picture and picture pada kelas eksperimen membuat peserta didik lebih aktif sehingga hasil belajar lebih baik dari pada kelas kontrol dengan pembelajaran konvensional melalui metode ceramah. 
Perbedaan signifikan antara kelompok siswa kelas eksperimen dengan kelas kontrol menunjukkan kompetensi pengetahuan dipengaruhi oleh model pembelajaran. Dapat diketahui bahwa pembelajaran biologi dengan model picture and picture membuat peserta didik lebih aktif, memudahkan pemahaman materi dan perhatian untuk belajar lebih tinggi. Menurut Riyono (2015: 171) dengan menggunakan model picture and picture memudahkan peserta didik dalam memahami materi. Hal ini sejalan dengan pendapat Fitriani dan Mahwar (2018: 19), model picture and picture dalam proses pembelajarannya dapat membantu peserta didik untuk belajar dengan baik dan peserta didik akan lebih aktif dalam mengikuti pembelajaran.

\section{Kompetensi Sikap}

Kompetensi sikap dalam pembelajaran merupakan serangkaian kegiatan yang dirancang untuk mengukur sikap peserta didik sebagai hasil dari suatu program pembelajaran. Sikap dapat dibentuk sehingga terjadi perilaku atau tindakan yang diinginkan (Majid dan Aep, 2014: 173). Menurut Lufri (2007: 134), sikap (attitude) didefinisikan sebagai suatu keadaan internal yang mempengaruhi individu terhadap tindakan yang terarah pada benda (objek) atau kejadian. Pada penelitian ini, kompetensi sikap dinilai oleh 3 orang observer menggunakan lembar observasi. Hasil kompetensi sikap kelas eksperimen yang diberi perlakuan dengan penggunaan model pembelajaran picture and picture lebih baik dari pada kelas kontrol yang tidak menggunakan model pembelajaran picture and picture. Kelas eksperimen memiliki rata-rata nilai 76,46 sedangkan kelas kontrol memiliki rata-rata nilai 66,54 .

Hasil uji normalitas menunjukkan bahwa data terdistribusi normal. Hal ini dibuktikan dengan L0 pada kelas eksperimen 0,14 dan Ltabel 0,173 dengan taraf nyata 0,05 . L0 < Ltabel maka data terdistribusi normal. Uji normalitas pada kelas kontrol diperoleh L0 0,13 dan Ltabel 0,161 dengan taraf nyata $0,05 . \quad$ L0 < Ltabel maka data terdistribusi normal. Hasil uji homogenitas kelas sampel diperoleh Fhitung 1,33 dan Ftabel 1,92 dengan taraf nyata 0,05 . Fhitung $<$ Ftabel yang berarti data memiliki varians yang homogen. Berdasarkan hasil uji normalitas yang menunjukkan data terdistribusi normal dan uji homogenitas yang menunjukkan data memiliki varians yang homogen maka peneliti mengunakan uji t untuk uji hipotesis. Hasil uji hipotesis diperoleh thitung 3,27 dan ttabel 1,67 dengan taraf nyata 0,05 . thitung $>$ ttabel maka $\mathrm{H} 0$ ditolak dan H1 diterima. Artinya terdapat pengaruh positif yang berarti terhadap kompetensi sikap peserta didik pada materi sistem ekskresi di MAN 3 Pesisir Selatan.

Model pembelajaran picture and picture pada kelas eksperimen dapat meningkatkan kompetensi sikap peserta didik karena picture and picture melatih kemampuan sosial peserta didik selama pembelajaran berlangsung. Peserta didik dilatih untuk menumbuhkan sikap gotong royong atau bekerjasama dengan baik dalam menyelesaikan tugas kelompok seperti menganalisa gambar maupun memberi penjelasan pada gambar sehingga komunikasi berjalan dengan baik. Hal ini sejalan dengan penelitian yang 
dilakukan Taniredja (2013: 55) menyatakan bahwa pembelajaran kooperatif picture and picture merupakan sistem pengajaran yang memberi kesempatan pada peserta didik untuk saling bekerja sama dalam mengerjakan tugas-tugas yang berstruktur, berkelompok, sehingga terjadinya interaksi secara terbuka dan hubungan yang baik diantara anggota kelompok.

\section{Kompetensi Keterampilan}

Penilaian keterampilan menuntut peserta didik mendemonstrasikan suatu kompetensi tertentu. Penilaian ini dimaksudkan untuk mengetahui apakah pengetahuan (KD pada KI-3) yang sudah dikuasai peserta didik dapat digunakan untuk mengenal dan menyelesaikan masalah dalam kehidupan sesungguhnya (real life) (Kemendikbud, 2017: 33).

Penilaian keterampilan dilakukan dengan berbagai teknik penilaian yang disesuaikan dengan karakteristik masing-masing Kompetensi Dasar. Teknik penilaian keterampilan yang digunakan pada penelitian ini berupa penilaian proyek. Penilaian proyek berupa laporan dilakukan melalui tiga kriteria penilaian yaitu perencanaan, pelaksanaan, dan pelaporan hasil. Instrumen yang digunakan berupa skor penilaian yang dilengkapi rubrik. Setiap kriteria tersebut terdiri dari beberapa indikator yang dikembangkan dari Direktorat Pembinaan SMA Ditjen Pendidikan Dasar dan Menengah tahun 2017 tentang Panduan Penilaian.

Berdasarkan hasil analisis observasi pada kompetensi keterampilan, nilai rata- rata kelas eksperimen lebih tinggi dibandingkan dengan kelas kontrol. Kelas eksperimen yang diberi perlakuan dengan menerapkan model pembelajaran picture and picture memiliki nilai rata-rata 86,81sedangkan kelas kontrol yang tidak menerapkan model pembelajaran picture and picture memiliki nilai rata-rata 81,39. Meskipun tidak berbeda jauh namun tetap terlihat bahwa nilai rata-rata pada kelas eksperimen lebih tinggi dibandingkan dengan kelas kontrol, hal ini bermaksud bahwa pembelajaran dengan menerapkan model picture and picture berpengaruh terhadap kompetensi keterampilan peserta didik.

Hasil uji normalitas menunjukkan bahwa data terdistribusi normal. Hal ini dibuktikan dengan L0 pada kelas eksperimen 0,13 dan Ltabel 0,173 dengan taraf nyata 0,05 . L0 < Ltabel maka data terdistribusi normal. Uji normalitas pada kelas kontrol diperoleh L0 0,14 dan Ltabel 0,161 dengan taraf nyata $0,05 . \quad$ L0 < Ltabel maka data terdistribusi normal. Hasil uji homogenitas kelas sampel diperoleh Fhitung 1,10 dan Ftabel 1,92 dengan taraf nyata 0,05 . Fhitung $<$ Ftabel yang berarti data memiliki varians yang homogen. Berdasarkan hasil uji normalitas yang menunjukkan data terdistribusi normal dan uji homogenitas yang menunjukkan data memiliki varians yang homogen maka peneliti mengunakan uji t untuk uji hipotesis. Hasil uji hipotesis diperoleh thitung 8,40 dan ttabel 1,67 dengan taraf nyata 0,05 . thitung > ttabel maka $\mathrm{H} 0$ ditolak dan H1 diterima. Artinya terdapat pengaruh positif yang berarti terhadap kompetensi keterampilan peserta didik pada materi sistem ekskresi di MAN 3 Pesisir Selatan. 


\section{KESIMPULAN DAN SARAN}

Berdasarkan hasil penelitian yang telah dilaksanakan maka disimpulkan bahwa model pembelajaran picture and picture berpengaruh positif terhadap kompetensi pengetahuan, sikap dan keterampilan peserta didik kelas XI MAN 3 Pesisir Selatan. Model pembelajaran picture and picture mempunyai tahapan-tahapan yang sistematis, oleh karena itu disarankan untuk memahami tahapan-tahapan agar sesuai dengan alokasi waktu belajar sehingga pembelajaran dapat terlaksana dengan baik.

\section{DAFTAR PUSTAKA}

Alvin, Qharin Syafitri, Nurhadi dan Ade Dewi Maharani. 2016. Pengaruh Penerapan Model Pembelajaran Picture and Picture Terhadap Hasil Belajar Bologi Siswa Pada Materi Sistem Gerak Manusia Kelas XI Ipa SMA N I Koto XI Tarusan. E-Journal. Volume 6. Nomor 3.

Fitriani, Desi, dan Mahwar Qurbaniah. 2018. Komparasi Model Example Non Example Dan Picture And Picture Terhadap Hasil Belajar Pada Sub Materi Tulang Sma N 2 Sungai Raya. Jurnal Bioeducation. Volume 1. Nomor 1.

Haryaman, Harid. 2017. Penerapan Model Picture and Picture untuk Meningkatkan Kemampuan Siswa dalam Mengelompokkan MacamMacam Tulang pada Rangka Manusia (PTK di Kelas VIII-K SMP Negeri 1 Rajapolah). Jurnal Wahana Pendidikan. Volume 4. Nomor 2.

Kemendikbud. 2017. Panduan Penilaian oleh

Pendidik dan Satuan Pendidikan SMA. Jakarta: Kemendikbud.

Lufri. 2007. Strategi Pembelajaran Biologi. Padang : UNP Press.
Majid, A \& A.S Firdaus. 2014. Penilaian Autentik. Bandung: Interes Media.

Natalina, M. 2011. Penerapan Model Pembelajaran Kooperatif Picture and Picture untuk Meningkatkan Aktivitas dan Hasil Belajar Biologi Siswa Kelas XI IPA SMA N 1 UKUI Tahun Ajaran 2009/2010. Jurnal Pendidikan Sains dan Biologi. Volume 7. Nomor 2.

Riyono, Bambang dan Amin Retroningsih. 2015. Efektivitas Model Pembelajaran Picture and Picture dengan Strategi Inkuiri Terhadap Motivasi dan Hasil Belajar Siswa. Unnes Journal of Biology Education. Volume 4. Nomor 2.

Taniredja, Tukiran. 2013. Model-Model Pembelajaran Inovatif dan Efektif. Bandung: Alfabeta.

Trianto. 2009. Mendesain Model-Model Pembelajaran Inovatif-Progresif. Jakarta: Kencana.

Yundani, Opi. 2017. Penerapan Model Pembelajaran Picture And Picture Dan Media Audio Visual Terhadap Hasil Belajar Siswa Pada Materi Struktur Dan Fungsi Tubuh Tumbuhan Di Kelas VIII SMP Negeri 1 Baitussalam. Skripsi. Aceh : Universitas Islam Negeri Ar-Raniry. 